Original article

\title{
Land accessibility constraints of migrants in rural border settlements of Ogun State,
}

Nigeria

\author{
Gbenga J. Oladehinde*, Lasun M. Olayiwola, Kehinde O. Popoola
}

${ }_{1}^{1}$ Department of Urban and Regional Planning, Obafemi Awolowo University, Ile-Ilfe, Osun State, Nigeria

E-mail address ( ${ }^{*}$ corresponding author): gbengom@gmail.com

\begin{abstract}
The study examined land accessibility constraints among migrants in rural border settlements of Ogun State, Nigeria. It specifically examined dimensions, extent of importance of the constraints and their joint interactive influence on land accessibility. Data were collected through questionnaires on migrant household heads. A multi-stage sampling technique was used for the selection of 492 respondents for the study. Data collected were analysed using descriptive and inferential statistics (t-test, relative important index (RII) and correlation statistics). The study revealed that the majority of the sampled migrants were within an active and productive population (31-60 years). Also, the larger percentage of the respondents were male (64.8\%), married (70\%), farmers (67.2\%) with no formal education (51.3\%). Most of the migrants have stayed above 6 years $(79.8 \%)$ in the study area. This is an indication that migrants would have detailed experience about their land accessibility constraints. Findings showed that the high cost of land was the major constraint to land accessibility and non-availability of land (scarcity) was the least constraint. The study further revealed that the high cost of land, inability to transfer land, difficulty in land transaction and insecure tenure jointly influenced migrants' access to land in the study area. The study therefore recommended the need for an efficient land administration and governance at local government level in order to accommodate the attendant needs of rural migrants in the study area.
\end{abstract}

KEY WORDS: migrants, rural border communities, land, land accessibility

ARTICLE HISTORY: received 13 December 2017; received in revised form 13 March 2018; accepted 14 March 2018

\subsection{Introduction}

Land as noted by the INTERNATIONAL FUND FOR AGRICUltural DEVElopment (IFAD) (2015) is fundamental to people in the developing world (and most importantly in rural areas), but unfortunately, its access is becoming more tenuous than ever. While the current trend in land administration and distribution in Sub-Saharan Africa and other developing countries has undermined security of tenure, sustainable natural resource management has failed to provide easy access to land (ODUM \& IBEM, 2011). Land access in rural communities of Nigeria is still by tenure. In Nigeria, the land tenure system varies with communities, tribes, and clans. In most rural areas of Nigeria, land is communally owned and traditionally no single person has exclusive rights over a piece of land. Land acquisition through inheritance occurs when a piece of land belonging to the ancestor is passed down to the next generation through the lineage. Most rural lands are tenured by inheritance and all members of such a lineage are assured of a piece of land. This has resulted in land fragmentation as the population increases from generation to generation, leading to reduced land availability. Rural migrants are therefore less privileged and often face discrimination in the struggles to have access to land because of the inherent and supposed natural dominance of land owners who control rights to land (DEPARTMENT FOR INTERNATIONAL DEVELOPMENT, 2007; LASTERRIA-CORNHIEL \& GRACIA, 2009).

In spite of the fact that past federal Government administrations have made concerted efforts in ensuring that land is accessible and affordable to the landless (migrants) through the promulgation of the Land Use Act of 1978. The problem that is associated with land tenure by inheritance still 
persists, as cases of land fragmentation and incessant communal conflict abound. Also, the 1999 constitution which was supposed to guarantee equal access to land for all Nigerians irrespective of their tribe, religion, occupation, level of education, political affinity and gender has failed to protect the right of migrants in the host communities.

As a result, migrants do not only have insecure land rights to invest on land, they also have little or no access to credit or the benefits of membership in rural organizations. This prompted migrants to resort to marginal land or occupy land informally. UN-HABITAT (1996) argued that access to land and security of tenure are strategic prerequisites for the progressive integration of the rural poor (especially migrants) and the development of human settlements. Secured land access will help to reverse three types of phenomena: gender discrimination; social exclusion of vulnerable groups; and wider social and economic inequalities linked to inequitable and insecure rights to land.

The alarming rate of lack of access to land has provoked researchers into some aspects of land accessibility studies (GBADEGESIN, 2016; ODUM \& IBEM, 2011; UDECHUKWU, 2008; ISHE, 2007; OLADEHINDE ET AL., 2017; ODUDU, 2015; ODUDU \& OMIRIN, 2012). Some of the shortcomings of the land accessibility studies include incessant rancour and litigation, fraudulent land sales, marginalisation of non-land holding families, stringent titling procedure, communal conflict, insecurity of tenure among others. Again, studies in Nigeria have identified accessibility as a major problem with the theoretical description of its dimensions. However, there is a dearth of empirical studies that have specifically pinpointed the actual constraints of land accessibility and their level of significance among migrants in rural border settlements of Ogun State. Apart from this, land accessibility in Ogun State, as earlier stated, is governed by the Land Use Act 1978 and 1999 constitution. The land law guaranteed easy access to land for all Nigerians irrespective of religion, tribe, gender, education, occupation, among others. However, in practice, accessibility to land is not only determined by law but also by the socioeconomic characteristics of the applicant. The law also does not make provision for ownership of land by persons who are migrants especially in the study area. It is against this background that this article examines land accessibility constraints among migrants in the rural border settlements of Ogun State, Nigeria.

\subsection{Conceptual issues}

Four terms were recognised in this articles, namely - land, land accessibility, migrants and rural border settlements.

Land is a unique, valuable, and immovable resource of limited quantity which contains valuable structures and natural resources on (or beneath) it (AZEEZ ET AL., 2016). It encompasses all attributes of the biosphere immediately above or below the earth's terrestrial surface, not exempting the soil, terrain, surface hydrology (including shallow lakes, rivers, marches, and swamps), the near surface climate, sediments and associated groundwater reserve, plant and animal populations, the human settlement pattern and physical results of past and present human activity such as terracing, water storage or drainage structures, roads, buildings, etc. (UNITED NATIONS, 1994).

According to IFAD (2006) land is an economic resource and an important factor in the formation of individual and collective identity, and in the day-to-day organization of social, cultural and religious life. It is also an enormous political resource that defines power relations between and among individuals, families and communities. UNITED NATIONS (2012) asserted that land is not only a valuable asset where national economies require land as an input for development, it is also an important safety net for the rural poor i.e. rural poor can fall back to it in extreme circumstances to ensure family survival through sales or subsistence farming. Land is used for the production of biomass, ensuring food, fodder, renewable energy and raw materials for the existence of human and animal life (BLUM, 1998). In a rural community, land is a fundamental factor of production. It plays an essential role in increasing as well as sustaining agricultural production. Land is therefore a basic source of livelihood providing employment, the key agricultural input, and a major determinant of access to other productive resources and services. In this regard, accessibility to land in urban and rural resettlements has been very competitive.

Land accessibility is described in terms of access and rights (UN-HABITAT, 2008). Access is defined as the ability to benefit, occupy or utilise land for the purposes of shelter, productive activity or the enjoyment of recreation and rest, whether temporarily or permanently (GBADEGESIN ET AL., 2016; CotUla ET AL., 2006). On the other hand, land rights are described as socially or legally recognized entitlements to access, use and control areas of land and related natural resources. It includes the right to: occupy, enjoy 
and use land and resources; cultivate and use land productively; restrict or exclude others from land; transfer, sell, purchase, grant or loan; inherit and bequeath; develop or improve; rent or sublet; and benefit from improved land value or rental income. Generally, land accessibility can be referred to as the processes by which people individually or collectively gain rights and opportunities to occupy and utilise land primarily for productive purposes and other economic and social purposes. Access to land can automatically mitigate the problems of homelessness, unsafe living and plays a vital role in poverty reduction and development. Similarly, access to land is a promising strategy for increasing migrants' productive capacity resulting in the promotion of human development and poverty reduction (OECD, 2001; WORLD BANK, 2003).

Scholars have identified different means of accessing land (VÉLEZ-GUERRA, 2004; ODUDU, 2015; OLADEHINDE ET AL., 2017; DRECHSEL \& DONGUS, 2009). In their various studies, they have noted that means of accessing land include leasing, inheritance, renting, borrowing, squatting and crop sharing. They further submitted that constraints to land accessibility are largely due to market constraints, insecure tenure, difficulty in land transaction, inability to transfer land, non-availability of land, inability to use land, high land competition with non-agricultural land use, poor soils and possible prosecution due to illegal use. Problems of land accessibility have caused people to migrate from place to place in search of "greener pastures".

Migrants can be understood as any person who moves from one place to another for the purpose of taking up permanent or semi-permanent residence. It also involves the movement of persons from one region to the other, whatever its length or duration, composition and causes (ECOWASSWAC, 2006). As noted by LEE (1969) there are two major factors which cause people to migrate. These include push and pull factors. Push factors are those factors that drive people away from their native land. Examples include: poverty, flood, conflict, landlessness, land fragmentation, environmental degradation, population pressure, recurrent drought and famine, war and political crises, unemployment, low income, crop failure, among others. Pull factors, on the other hand, are those factors that attract people to an area of destination. Examples are: availability of vacant and fertile land, political freedom, job opportunities, better quality of life, and increase in income among others. Of relevance to this article is migration due to landlessness or inaccessibility to land.
Moreover, FADAYOMI (1998) and AMSELLE (1985) have explained different patterns of migration; these are rural to rural, rural to urban, urban to rural, or urban to urban. Of concern to this study is migration (international and internal migration) to rural border settlements. Rural border settlements according to BENNETT (2009) are communities closer to the "international" border line between two countries, states or regions with simple life, agriculture, small in shape, homogeneity, dullness (with little or no social activities) and smuggling. They could have the features of a highly cosmopolitan town or flashpoint for extreme rural areas (WILLS, 2010). IFAD (2001) observed that they constitute commercial centres for agricultural goods, and also where human settlement and infrastructure occupy only small patches of land; most of the landscape of which are dominated by fields and pastures, woods and forest, mountain and desert. One of the peculiarities of the settlements is that despite the fact that the communities lack virtually all the good things of life like roads, medical and health facility, potable water, electricity, good communication network among others, the settlements also serve as point of attraction to migrants from other countries into these areas and the peculiarity of these settlements is really becoming popular (AFOLAYAN, 2010).

Popoola (2016) asserted that migrants are more likely to settle in a nearer place which they have more knowledge of than in a farther place which they know but understand little about. In other words the shorter the distance from a given location, the better the understanding of that location and vice versa. OLADEHINDE (2016) opined also that migrants are more likely to settle where they have a network of friends and families than in an area where they do not. Friends and family not only provide information about the settlement, they also provide accommodation for the new migrants.

Despite all the reasons which cause migrants to be attracted to rural border settlements CORNHIEL \& FRAIS (2009) noted that migrants (as strangers) in a foreign land are less privileged and often face discrimination and limited access to rural land because of the inherent and supposed natural dominance of the indigene (king, family and community) who control rights to land over migrants who do not. This type of dominance has in turn rendered the right of migrants to land to be insecure. Another reason for the insecure access to land in rural communities of Nigeria is attributed to poor or weak customary tenure arrangements and land administration by government which does not recognise migrants' status (AGWU ET AL., 
2010). The extent, or level, of accessibility to land by migrants in rural border settlements of Ogun State is the focus of this study.

\subsection{The study area}

The study area, Ogun State, is one of the fastest developing states in Nigeria; lying in the south western part of the country between on latitude $6.2^{\circ} \mathrm{N}$ and $7.8^{\circ} \mathrm{N}$ and longitude $3.0^{\circ}$ and $5.0^{\circ} \mathrm{E}$ east of the Greenwich Meridian. The state is bounded on the west by the Republic of Benin and on the east by Ondo State. To the north is Oyo State while Lagos State and the Atlantic Ocean are to the south (Fig. 1.). The geographical location of the state makes it accessible to the economically developed regions in Nigeria.

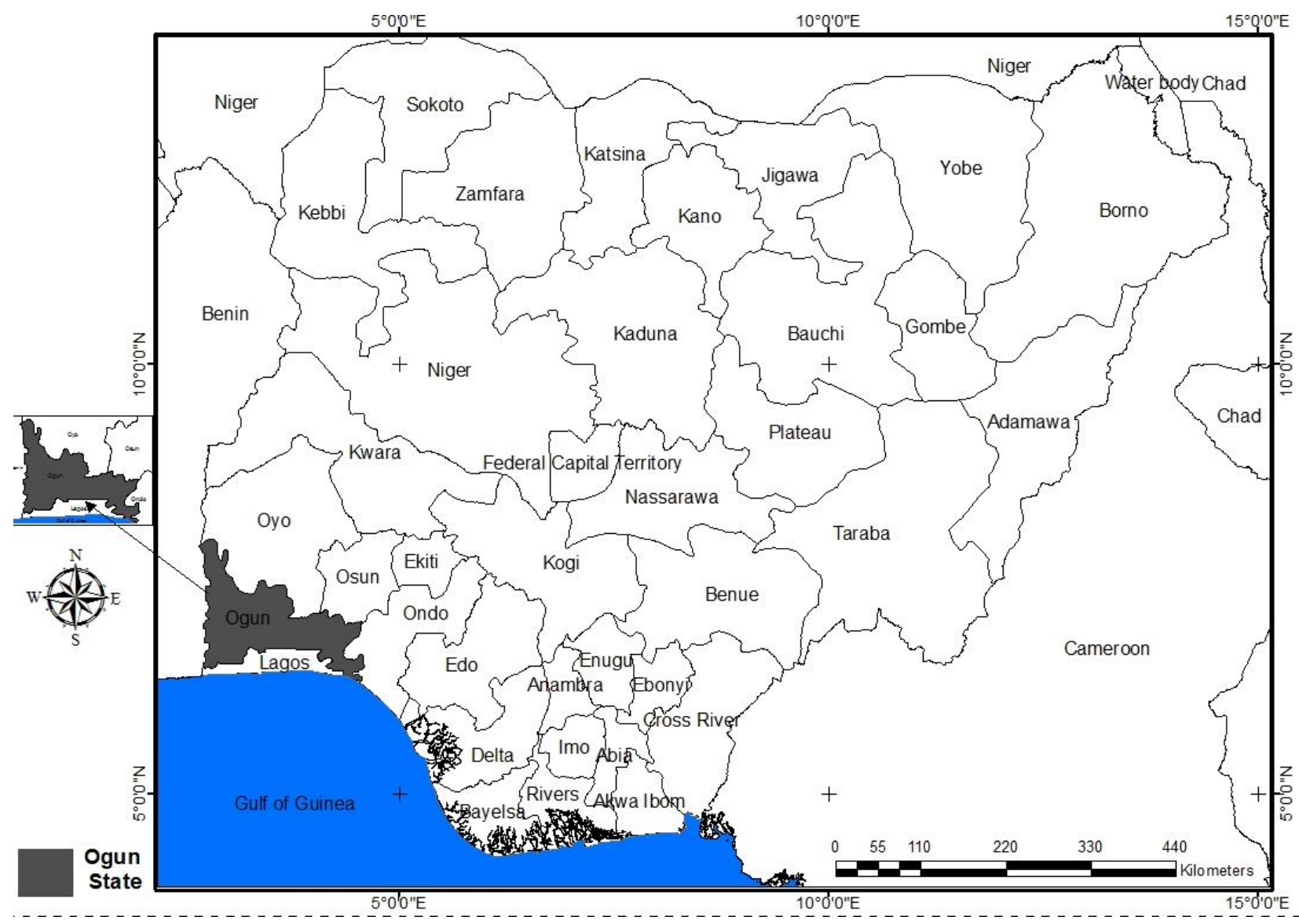

Fig. 1. Map of Nigeria showing the boundary of Ogun State, other States and neighbouring Countries

(Source: Ogun State, Ministry of Land and Housing, 2017)

Ogun State is made of up 20 local government areas. Of importance to this study are Ipokia, Yewa North and Imeko/Afon, because they share a border with the Republic of Benin (Fig. 2). The populations of Ipokia, Yewa North and Imeko/Afon are 150,426 (2006 census), 181, 826 (2006 census) and 118,339 (1991 census) respectively while their population density includes 336 persons $/ \mathrm{km}^{2}$ (Ipokia), 114 persons $/ \mathrm{km}^{2}$ (Yewa North) and 51persons $/ \mathrm{km}^{2}$ (Imeko Afon) (Ogun State Central Department OF STATISTICS, 2008). Also the local governments (Ipokia, Yewa North and Imeko/Afon) have called Ogun State the 'gateway' to Nigeria from other coastal West African countries like Benin and Republic of Togo, Ghana, Sierra Leone and Liberia (OJIAKO ET AL., (2014). Residents in these local government areas are called Yewa (after the name of River Yewa), a clan of the Yoruba people, they inhabit the eastern area of Ogun west senatorial District, Ogun State, in south-west Nigeria. The Yewa clan comprises of four local governments, which include Yewa South, Yewa North, Imeko-Afon and Ipokia. One of the peculiarities of these local governments are their ability to attract migrants from West Africa and people from other Nigerian ethnic groups who find it conducive to living and investing in (ODUGBEMI, 1993; OJIAKO ET AL., (2014).

The major occupation of the people in these communities is arable farming. They cultivate cassava and maize. Also fishing is practiced on River Yewa by some inhabitants of the area to supplement their food crops. 


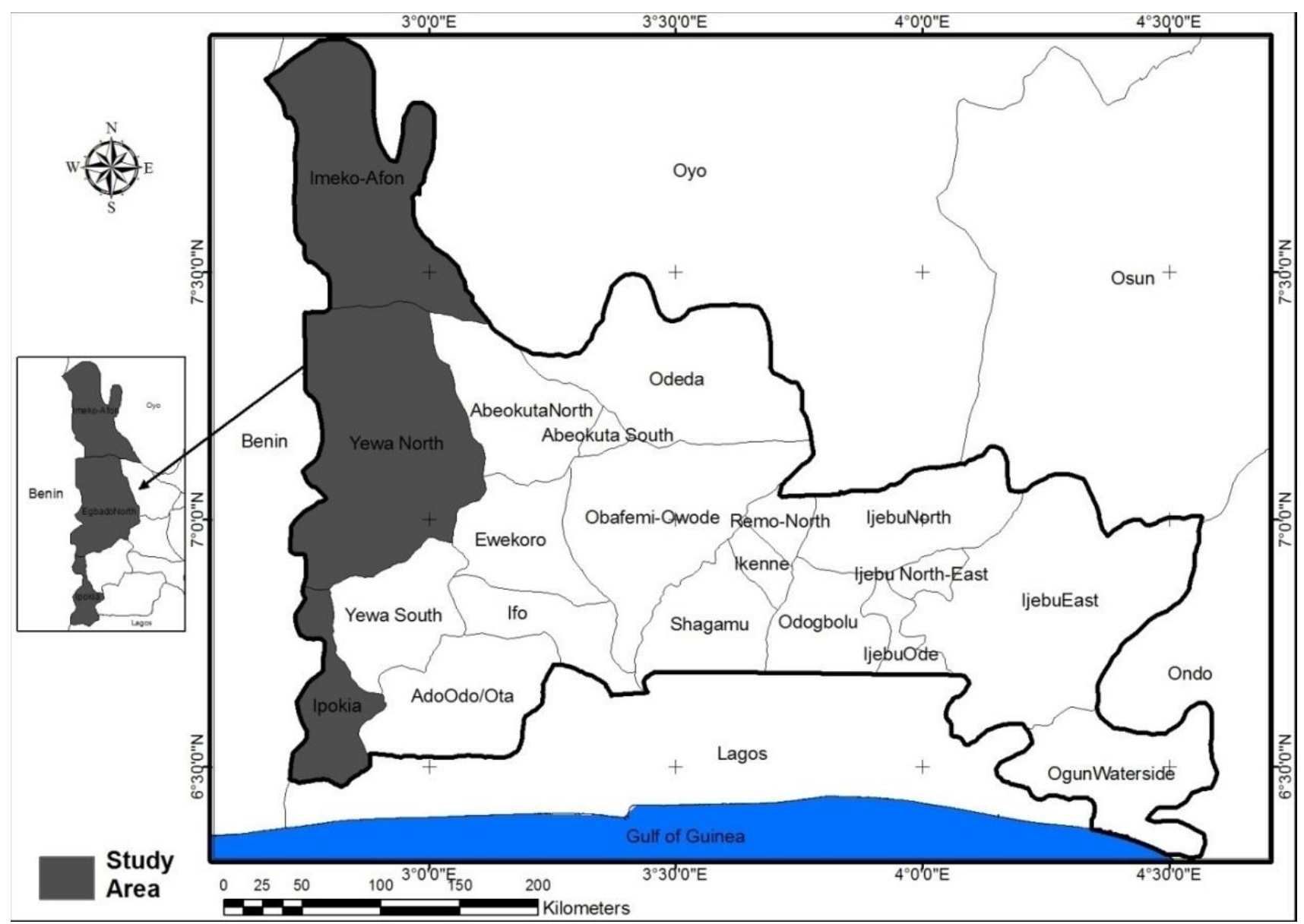

Fig. 2. Map of Ogun State showing the Study Area: Ipokia,Yewa North, Imeko/Afon (Source: Ogun State, Ministry of Land and Housing, 2017)

\section{Method}

A multi-stage sampling technique was employed for the survey of the selected rural border settlements. The first stage involved identification of Local Government Areas (LGAs) that shared boundaries with the Republic of Benin. Information from the pilot survey revealed that out of the twenty local government areas in Ogun State, three LGAs shared boundaries with the Republic of Benin, These are Yewa North, Imeko/Afon and Ipokia and all of them were selected for the study.

The next stage was the identification of settlements with clustering of cross border migrants in the three Local Government Areas. The identified settlements were those that fall within $15 \mathrm{~km}$ from the International Boundary line (HARVEY, 2008) and these were: Tube, Ibatefin, Idolosa, Ago sasa, Ileodun Aye, Idimarun, Oniro, Ago Egun, Idoforo, Itaegbe, Paagbon, Idabata, Bode Ase, Sekoji, Ikefin, Pedepo, Ohunbe, Igbeme, Ojumo, Gbokoto, Abepe, Obelle, Ibayun, Ijoko, Amiju, Abule Idi, Arete, Ago Ajeri, Ologori; Iwoye, Idiyan, Idofa, Ajekota, Ijumo, Ologori, Ishukun, Wasimi Okuta, Ajirin and Tobolo.

In the third stage, one out of every four villages of the identified settlements were randomly selected without replacement and these included Ago Egun, Idabata, Paagbon, Bode Ase, Idolosa, Pedepo, Gbokoto, Ijoko, Abule Idi, Iwoye, Ajekota and Wasimi-okuta.

In the fourth stage, migrants were selected through the use of systematic random sampling techniques. This started with the selection of the first building (occupied by migrants). The subsequent units of the investigation were every second building of the designated place for migrants in each selected villages. The next building was sampled in a situation where there was no migrant in the second building. In each of the selected buildings, a questionnaire was administered to the head of the migrant household.

Using this procedure, a total of 492 questionnaires were administered in the study area. It must be noted that out of these, 491 questionnaires across the study area were duly completed and retrieved. Secondary data were obtained from documentary sources. Descriptive and inferential statistics were employed for data analysis. Information that was collected from migrant household heads included socio-economic background and land accessibility characteristics. 


\subsection{Data analysis}

Data that were generated from the field work were analysed using descriptive (frequency distribution, percentages and tables) and inferential (t-test, Relative Importance Index (RII) and correlation statistics).

In the calculation of the Relative Importance Index (RII), the formula below was used:

$$
\mathrm{RII}=\frac{2 W}{A * N}
$$

where:

$W$ - weighting given to each statement by the respondents and ranges from 1 to $5, A$ - higher response integer (5): and $N$ - total number of respondents.

Thus, the higher the RII, the higher the constraint attached to land accessibility with the element under consideration. This model was found useful while examining the impact, or significance level, of one constraint on the other.

\section{Results and discussion}

\subsection{Socio-economic characteristics of the migrants}

Table 1 revealed that more than $70 \%$ of the sampled migrants were in the 31-60 years age bracket, $23.6 \%$ were between $1-30$ years while barely $3.7 \%$ were of 60 years and above. This suggests that the majority of the migrants were within the active population and that younger people in the active population migrate more than other age groups in the rural border settlements. It can be observed in the table that more men migrate than women, due to their role and function in the family, as $64.8 \%$ of the respondents were males while $35.2 \%$ were females. Table 1 also shows that importance was attached to marriage than singleness as more than $70 \%$ of the sampled respondents were married while $10.8 \%, 11.2 \%$ and $6.7 \%$ were single, separated and widowed respectively.

A larger percentage $(51.3 \%)$ of the respondents contacted had no formal education, about $34.8 \%$ and $11.6 \%$ of the sample had primary and secondary school education respectively, while quite a few $(2.2 \%)$ had tertiary education. This suggests that over half of the migrant household heads were not formally educated and their level of education can influence the type of job they take up to earn their living. Based on the information in Table 1, $67.2 \%$ of the respondents were undertaking farming activities such as cultivation of crops (i.e. vegetables, beans, peppers, cassavas, yams, among others)
Table 1. Socio-economic characteristics of the respondents (Source: Author's field work in 2017)

\begin{tabular}{|c|c|c|}
\hline Variables & Frequency & Percentage \\
\hline \multicolumn{3}{|l|}{ Age } \\
\hline $0-30$ & 116 & 23.6 \\
\hline $31-60$ & 375 & 72.7 \\
\hline Above 60 & 18 & 3.7 \\
\hline \multicolumn{3}{|l|}{ Gender } \\
\hline Male & 318 & 64.8 \\
\hline Female & 173 & 35.2 \\
\hline \multicolumn{3}{|l|}{ Marital status } \\
\hline Single & 53 & 10.8 \\
\hline Married & 350 & 71.3 \\
\hline Separated & 55 & 11.2 \\
\hline Widow/widower & 33 & 6.7 \\
\hline \multicolumn{3}{|l|}{ Educational qualification } \\
\hline No formal education & 252 & 51.3 \\
\hline Primary school & 171 & 34.8 \\
\hline Secondary school & 57 & 11.6 \\
\hline Tertiary & 11 & 2.2 \\
\hline \multicolumn{3}{|l|}{ Occupation } \\
\hline Unemployed & 22 & 4.7 \\
\hline Farming & 330 & 67.2 \\
\hline Trading & 82 & 16.7 \\
\hline Civil Servants & 1 & 0.2 \\
\hline Smuggling & 56 & 11.4 \\
\hline \multicolumn{3}{|l|}{ Ethnicity } \\
\hline Benin & 399 & 81.3 \\
\hline Togo & 31 & 6.3 \\
\hline Ghana & 29 & 5.9 \\
\hline Nigeria & 32 & 6.5 \\
\hline \multicolumn{3}{|l|}{ Monthly income } \\
\hline Below $18000(\$ 50)$ & 152 & 31.0 \\
\hline $18001(\$ 50)-55000(\$ 152.8)$ & 323 & 65.8 \\
\hline $55001(\$ 152.8)-74000(\$ 205.6)$ & 12 & 2.4 \\
\hline Above $74001(\$ 205.6)$ & 4 & 0.8 \\
\hline \multicolumn{3}{|c|}{ Length of stay in the study area (years) } \\
\hline $1-5$ & 104 & 21.2 \\
\hline $6-10$ & 99 & 20.2 \\
\hline $11-15$ & 117 & 23.8 \\
\hline $16-20$ & 115 & 23.4 \\
\hline 21 above & 56 & 11.4 \\
\hline
\end{tabular}

and rearing of animals (i.e. cows, goats, sheep, among others). Trading ranked second amongst the migrants in the study area. The household heads who were undertaking trading constituted $16.7 \%$. Following farming and trading are household heads 
that are engaged in smuggling (11\%) (i.e. smuggling of vehicles, drugs, rice, vegetable oil, turkey, arms and ammunitions and textiles among others) while a smaller proportion of the sample were unemployed (4.7\%) and civil servants $(0.2 \%)$. Information on the nationality of the respondents revealed that the majority of the respondents were from other countries to the west of Nigeria (i.e. Republic of Benin, Togo and Ghana). For instance, $81.3 \%$ of the sample were from Benin Republic, 6.3\% from Togo and 5.9\% from Ghana, while 6.5\% of the migrants were from Nigeria (i.e. native migrants that were not from the study area). Information on the income of household heads revealed that $69.6 \%$ of the migrants earned between $\$ 50(\mathrm{~N} 18,000)$ and $\$ 152.8(\mathrm{~N} 55,000)$ per month, about $31 \%$ earned below $\$ 50(\mathrm{~N} 18,000)$ while quite a few (3.2\%) earned above 152.8 (N55,001) per month. This suggests that the majority of the migrants earned above the Nigerian minimum wage $(\$ 50)$ despite the fact that they are in rural border settlements.

Analysis of the migrants' length of stay in the study area, as shown in Table 1, revealed that $23.8 \%$ of the migrants stayed between $11-15$ years, $23.4 \%$ stayed between $16-20$ years, $21.2 \%$ stayed between $1-5$ years, $20.2 \%$ stayed between $6-10$ years while $11.4 \%$ stayed above 21 years in the study area. It can be inferred that migrants that have stayed above 6 years $(79.8 \%)$ would have a more detailed experience in the rural border settlements than other migrants below 5 years.

\subsection{Modes of accessing land in the study area}

Table 2 revealed that $35.4 \%$ of migrants accessed their land by renting, $21.3 \%$ by leasing and $12.5 \%$ by community allocation. This reflects the general means of accessing land in other rural areas in Nigeria (i.e. through rent, lease and community allocation). Also, $6.6 \%$ of the migrants accessed the land by share cropping, while $6.2 \%$ and $4.9 \%$ accessed the land by purchase and inheritance respectively. The proportion of migrants that accessed the land by gifting was $4 \%$ while 9.1\% accessed the land by other means (i.e squatting, borrowing, permission to use, among others). In addition, none of the respondents had access to land through government allocation. The findings generally agreed with VELEZ-GUERRA (2004) and NuWAGABA ET AL, (2003) who identified multiple means of land access as renting, inheritance, borrowing, squatting, leasing, among others. It can also be observed that an informal method was the fundamental source of access to land in the study area.
Table 2. Migrants' mode of accessing land in the study area (Source: Author's field survey (2017)

\begin{tabular}{|l|c|c|}
\hline Mode & Frequency & Percentage \\
\hline Rent & 451 & 35.4 \\
\hline Leasing & 271 & 21.3 \\
\hline Community allocation & 159 & 12.5 \\
\hline Share cropping & 84 & 6.6 \\
\hline Purchase & 79 & 6.2 \\
\hline Inheritance & 63 & 4.9 \\
\hline Gift & 52 & 4 \\
\hline Government allocation & 0 & 0 \\
\hline Other means & 116 & 9.1 \\
\hline Total & $* 1275$ & 100 \\
\hline
\end{tabular}

Note: *Higher than the total survey because of multiple responses

\subsection{Land size and duration of land usage}

Analysis of the farm size in Table 3 shows that $96.3 \%$ of the migrant household heads have a farm size of less than 1.9 ha while $3.7 \%$ represented a small proportion of the respondents that have a farm size of above 2.0 ha in the study area. This implied that the majority of the migrants are small scale land holders. This could be attributed to the land tenure system in the study area. Also the farm sizes could be due to the financial constraints which make purchase, or rent, of land difficult in the study area. This finding is not far from the farm size of rural communities in other states in Nigeria (less than 1.9 ha).

Table 3. Farm size and duration of land usage (Source: Author's field work, 2017)

\begin{tabular}{|l|c|c|}
\hline \multicolumn{1}{|c|}{ Farm size } & Frequency & Percentage \\
\hline Below 1ha & 254 & $51.7 \%$ \\
\hline $1-1.9$ ha & 219 & $44.6 \%$ \\
\hline $2-2.9$ ha & 16 & $3.3 \%$ \\
\hline Above 3 ha & 2 & $0.4 \%$ \\
\hline Total & 491 & $100 \%$ \\
\hline Duration of land usage & & \\
\hline Below 1 yr & 45 & $9.2 \%$ \\
\hline 2 - 3 yrs & 345 & $70.3 \%$ \\
\hline 4 - 5 yrs & 73 & $14.9 \%$ \\
\hline 6 - 7 yrs & 13 & $2.6 \%$ \\
\hline Above 8 yrs & 15 & $3.1 \%$ \\
\hline Total & 491 & $100 \%$ \\
\hline
\end{tabular}


Further analysis on the duration of land usage as shown in Table 3 revealed that the majority $(79.5 \%)$ of the respondents' duration of land usage were below 3 years, followed by $4-5$ years $(14.9 \%)$, 6-7 years $(2.6 \%)$ and above 8 years (3.1\%). It can be observed that the majority duration of the respondents' land usage was below 3 years. This could be as a result of different modes of accessing the land in the study area (i.e. purchase, rent, least, inheritance, gift among others). This supports the assertion of CHUP (2004) and GHEBRU ET AL. (2014) that the duration of land usage can be attributed to the method of accessing the land. In other words, the existing methods of land accessibility have an influence on the duration of land usage in the study area.

\subsection{Land accessibility constraints}

Studies of ADAmU (2014) and ODUDU (2015) have confirmed different constraints in land accessibility. These constraints include the high cost of land, inadequate land, inability to use land, inability to transfer land, difficulty in land transaction and insecure tenure. These constraints were considered in order of their influence in the study. Table 4 presents the results of findings on the land accessibility constraints in the study area.

Using the overall mean value (14.36) of all the indicators of land accessibility constraints, the results in Table 4 show that each constraint is significantly different from the group mean value at 0.05 level of confidence. Evidence in the table indicates that the high cost of land has the highest t-value and mean of 3.88 and 100.4 respectively, followed by insecure tenure which has the second most important land accessibility constraint with a tvalue of 48.72 and a mean value of 3.21 . The next constraints in the order include difficulty in land transaction (t-value 40.88 and mean value 2.02), inability to transfer land (t-value 40.85 and mean value 2.02), inability to use land (t-value 40.54 and mean value 1.93) while the lowest was nonavailability of land (t-value 39.86 and mean value 1.28).

Table 4. One sample t-test of land accessibility constraints affecting migrants (Source: Author's field work, 2017)

\begin{tabular}{|l|c|c|c|c|c|c|c|}
\hline \multicolumn{1}{|c|}{ Constraints } & $\mathrm{N}$ & Mean & Std. Deviation & Std. Error Mean & $\mathrm{T}$ & Df & Sig. (2-tailed) \\
\hline High cost of land & 491 & 3.8778 & .85556 & .03861 & 100.433 & 490 & .000 \\
\hline Nonavailability of land & 491 & 1.2790 & .57281 & .02585 & 39.862 & 490 & .000 \\
\hline Inability to use land & 491 & 1.9328 & 1.05635 & .04767 & 40.543 & 490 & .000 \\
\hline Inability to transfer land & 491 & 1.9491 & 1.05727 & .04771 & 40.850 & 490 & .000 \\
\hline Difficulty in land transaction & 491 & 2.0224 & 1.09615 & .04947 & 40.883 & 490 & .000 \\
\hline Insecure tenure & 491 & 3.2077 & 1.45883 & .06584 & 48.723 & 490 & .000 \\
\hline
\end{tabular}

To establish the relative, or comparative extent at, to which land accessibility constraints have influence on migrants' activities in the study area there is a need to assess their level of agreement with the identified indicators. This was measured using a Likert Scale of five levels ranging from Strongly Agree (SA), Agree (A), Partially Agree (PA), Disagree (D) and Strongly Disagree (SD). The analysis of responses from the respondents evolved into an index called a Relative Important Index (RII)In order to arrive at the RII, a weighted value of 5, 4, 3, 2 and 1 were attached to ratings of strongly agree, agree, partially agree, disagree and strongly disagree respectively. Relative Importance Index, or weight, is a type of relative importance analysis and was used for the analysis because it best fits the purpose of this study. According to Johnson and LEBRETON (2004), RII aids in finding the contribution a particular variable makes to the prediction of a criterion variable both by itself and in combination with other predictor variables.

This model was used by SOMIAH ET AL., (2015) and BADU ET AL., (2013) to determine the relative importance of the various causes of siting unauthorised residential buildings and rural infrastructural development in the Volta Region of Ghana.

Table 5 shows the extent to which each constraint influences land accessibility to migrants in the study area. In line with previous findings (Table 4) the high cost of land (0.776) has the highest level of significance (influence) on migrants, followed by insecure tenure (0.642), difficulty in land transaction (0.404), inability to transfer land among migrants (0.390), inability to use land (0.387), while the least constraint is the nonavailability of land (0.256). 
Table 5. The relative extent to which each constraint influences land accessibility for migrants (Source: Author's field work, 2017)

\begin{tabular}{|c|c|c|c|c|c|c|c|c|c|c|c|c|c|}
\hline \multirow{2}{*}{$\begin{array}{l}\text { Accessibility } \\
\text { constraints }\end{array}$} & \multicolumn{2}{|c|}{ SD } & \multicolumn{2}{|c|}{ D } & \multicolumn{2}{|c|}{ PA } & \multicolumn{2}{|c|}{ A } & \multicolumn{2}{|c|}{ SA } & \multirow[t]{2}{*}{ Total } & \multirow[t]{2}{*}{ RII } & \multirow[t]{2}{*}{ Rank } \\
\hline & $\mathrm{F}$ & $\%$ & $\mathrm{~F}$ & $\%$ & $\mathrm{~F}$ & $\%$ & $\mathrm{~F}$ & $\%$ & $\mathrm{~F}$ & $\%$ & & & \\
\hline High cost of land & 12 & 2.4 & 7 & 1.4 & 120 & 24.4 & 242 & 49.3 & 110 & 22.2 & 1904 & 0.776 & $1^{\text {st }}$ \\
\hline $\begin{array}{l}\text { Non availability of } \\
\text { land }\end{array}$ & 385 & 78.4 & 75 & 15.3 & 31 & 6.3 & 0 & 0 & 0 & 0 & 628 & 0.256 & $6^{\text {th }}$ \\
\hline Inability to use land & 225 & 45.8 & 132 & 26.9 & 84 & 17.1 & 42 & 8.6 & 8 & 1.6 & 949 & 0.387 & $5^{\text {th }}$ \\
\hline $\begin{array}{l}\text { Inability to transfer } \\
\text { land }\end{array}$ & 221 & 45.0 & 132 & 26.9 & 88 & 17.9 & 42 & 8.6 & 8 & 1.6 & 957 & 0.390 & $4^{\text {th }}$ \\
\hline $\begin{array}{l}\text { Difficulty in land } \\
\text { transaction }\end{array}$ & 206 & 42.0 & 137 & 27.9 & 93 & 18.9 & 41 & 8.4 & 14 & 2.9 & 993 & 0.404 & $3^{\text {rd }}$ \\
\hline Insecure tenure & 69 & 14.1 & 134 & 27.3 & 54 & 11.0 & 94 & 28.5 & 140 & 19.1 & 1575 & 0.642 & $2^{\text {nd }}$ \\
\hline
\end{tabular}

The implication of this is that land is physically available in border settlements since it has the lowest level of influence on accessibility. This finding agrees with the assertion of BELLO (2009) and GBEDEGESIN ET AL. (2016) that land is physically available; the major difficulty in land accessibility includes the high cost of land, and insecure tenure among others. These findings also corroborate the earlier assertion of MUBVAMI ET AL. (2003) that land may be available but it may not be affordable (i.e. a high cost of land is attached to available land) even where it is affordable it may not have secure security of tenure. Also, where the tenure is secure, there may be a problem, or difficulty, in land transaction and sometimes migrants may not be able to transfer the available land to another person. In view of this the migrants' right to land for food, shelter, work, water among others is not secured. There is a lack of confidence in the authenticity of land and the ability of the respondents in utilising the land to its fullest is not there. Table 6 presents the extent of the relationship between land accessibility constraint indicators.

Table 6. Correlations between land accessibility constraint indicators in the study area (Source: Author's field work, 2017)

\begin{tabular}{|c|c|c|c|c|c|c|c|}
\hline \multicolumn{2}{|c|}{ Constraint } & \multirow{2}{*}{$\begin{array}{r}\begin{array}{c}\text { High cost } \\
\text { of land }\end{array} \\
1 \\
\end{array}$} & \multirow{2}{*}{\begin{tabular}{|c|}
$\begin{array}{c}\text { Non- availability } \\
\text { of land }\end{array}$ \\
-.069 \\
\end{tabular}} & \multirow{2}{*}{\begin{tabular}{c|}
$\begin{array}{c}\text { Inability to } \\
\text { use land }\end{array}$ \\
-.056 \\
\end{tabular}} & \multirow{2}{*}{$\begin{array}{c}\begin{array}{c}\text { Inability to } \\
\text { transfer land }\end{array} \\
.205^{* *} \\
\end{array}$} & \multirow{2}{*}{\begin{tabular}{|c|}
$\begin{array}{c}\text { Difficulty in land } \\
\text { transaction }\end{array}$ \\
$.988^{* *}$ \\
\end{tabular}} & \multirow{2}{*}{$\begin{array}{c}\begin{array}{c}\text { Insecure } \\
\text { tenure }\end{array} \\
.172^{* *} \\
\end{array}$} \\
\hline \multirow{3}{*}{$\begin{array}{l}\text { High cost of } \\
\text { land }\end{array}$} & Pearson Correlation & & & & & & \\
\hline & Sig. (2-tailed) & & .135 & .227 & \begin{tabular}{|r|}
.000 \\
\end{tabular} & \begin{tabular}{|c|}
.000 \\
\end{tabular} & .000 \\
\hline & $\mathrm{N}$ & 469 & 469 & 469 & 469 & 469 & 469 \\
\hline \multirow{3}{*}{$\begin{array}{l}\text { Non } \\
\text { availability } \\
\text { of land }\end{array}$} & Pearson Correlation & -.069 & 1 & $.211^{* *}$ & -.051 & -.089 & -.019 \\
\hline & Sig. (2-tailed) & .135 & & .000 & .274 & .055 & .687 \\
\hline & $\mathrm{N}$ & 469 & 469 & 469 & 469 & 469 & 469 \\
\hline \multirow{3}{*}{$\begin{array}{l}\text { Inability to } \\
\text { use land }\end{array}$} & Pearson Correlation & -.056 & $.211^{* *}$ & 1 & -.036 & -.074 & -.045 \\
\hline & Sig. (2-tailed) & .227 & .000 & & .432 & .109 & .332 \\
\hline & $\mathrm{N}$ & 469 & 469 & 491 & 469 & 469 & 469 \\
\hline \multirow{3}{*}{$\begin{array}{l}\text { Inability to } \\
\text { transfer land }\end{array}$} & Pearson Correlation & $.205^{* *}$ & -.051 & -.036 & 1 & $.212^{* *}$ & $.124^{* *}$ \\
\hline & Sig. (2-tailed) & .000 & .274 & .432 & & .000 & .007 \\
\hline & $\mathrm{N}$ & 469 & 469 & 469 & 469 & 469 & 469 \\
\hline \multirow{3}{*}{$\begin{array}{l}\text { Difficulty in } \\
\text { land } \\
\text { transaction }\end{array}$} & Pearson Correlation & $.988^{* *}$ & -.089 & -.074 & $.212^{* *}$ & 1 & $.185^{* *}$ \\
\hline & Sig. (2-tailed) & .000 & .055 & .109 & .000 & & .000 \\
\hline & $\mathrm{N}$ & 469 & 469 & 469 & 469 & 469 & 469 \\
\hline \multirow{3}{*}{$\begin{array}{l}\text { Insecure } \\
\text { tenure }\end{array}$} & Pearson Correlation & $.172^{* *}$ & .019 & -.045 & $.124^{* *}$ & $.185^{* *}$ & 1 \\
\hline & Sig. (2-tailed) & .000 & .687 & .332 & .007 & .000 & \\
\hline & $\mathrm{N}$ & 469 & 469 & 469 & 469 & 469 & 469 \\
\hline
\end{tabular}

**. Correlation is significant at the 0.05 level (2-tailed) 
The results in Table 6 indicate that the high cost of land positively correlated with an inability to transfer land $\left(0.205^{* *}\right)$, difficulty in land transaction $\left(0.988^{* *}\right)$, insecure tenure $\left(0.172^{* *}\right)$ and such correlations were significant at the 0.05 level. This implies that the extent of the joint influence of the high cost of land with other constraint indicators is very strong and very important. Also the non-availability of land is negatively correlated with other constraints and such correlations were not significant at the 0.05 level except inability to use land $\left(0.211^{* *}\right)$ which is positively correlated and significant at the 0.05 level. This implies that land accessibility constraint is not an issue of non-availability of land, land is available in the study area and it is only influenced by an inability to use the land. This is in line with MUBVAMI ET AL. (2003) who assert that land is either not available, or when it is available it may not be accessible, and when it is accessible it may not be usable for a particular purpose especially for rural migrants. The table shows that an inability to use land is positively correlated with the non-availability of land $\left(0.211^{* *}\right)$ at the 0.05 level of significance and negatively correlated with other constraints such as the high cost of land (-.056), inability to transfer land (-.036), difficulty in land transaction $(-.074)$ and insecure tenure $(-.045)$.

Furthermore, an inability to transfer land positively correlated with the high cost of land $\left(.205^{* *}\right)$, difficulty in land transaction $\left(0.212^{* *}\right)$ and insecure tenure $\left(0.124^{* *}\right)$ at the 0.05 level of significance and negatively correlated with the non-availability of land (-0.051) and inability to use land (-0.036). Also difficulty in land transaction correlated positively with high cost of land $\left(.988^{* *}\right)$, inability to transfer land $\left(.212^{* *}\right)$ and insecure tenure $\left(.185^{* *}\right)$ at 0.05 level of significant while insecure tenure is found to be positively and significantly correlated with high cost of land $\left(.172^{* *}\right)$, inability to transfer land $\left(.124^{* *}\right)$ and difficulty in land transaction $\left(.185^{* *}\right)$. This implies that the high cost of land, an inability to transfer land, difficulty in land transaction and insecure tenure jointly influence land accessibility in rural border settlements of Ogun State, Nigeria. In other words, land is available and the available land is usable, the constraints which make land inaccessible to migrants include the high cost of land, inability to transfer land, difficulty in land transaction and insecure tenure in the study area. The foregoing observation confirms the assertion of WEBER (2012) that border settlements are characterized with vast land which can be used for farming, housing development, rural market, work area, amongst others. It also supports the findings of the NATIONAL
HOUSING (1991), BOONYABANCHA (2009), OdUdU (2015), ODUDU \& OMIRIN (2012), OMIRIN (2002) that land accessibility constraints encompasses insecure tenure, cost of land and ease with which land is acquired. It revealed the significance of each constraint on land accessibility.

\section{Recommendations and conclusion}

The study has examined the land accessibility constraints among migrants in rural border settlements of Ogun State. The study discovered that while the high cost of land, insecure tenure, difficulty in land transaction and inability to transfer land are four major constraints to land accessibility in the study area, non-availability of land and inability to use land were considered as least constraints. It also discovered that the extent of the joint influence of non-availability and inability to use land with other constraints on land accessibility is not strong and are negatively correlated. While all the constraints are related, it is further observed that the insecure tenure, high cost of land, inability to transfer land and difficulty in land transaction are jointly related to the influence of land access in the rural border settlements of Ogun State.

Having identified the dimension and how all the constraints are related, it is important that land administration and governance at local government level should be more efficient in order to accommodate the attendant needs of the vulnerable (land-less or nearly land-less, especially migrants) in the study area. Also, programmes that will support the full integration of migrants' activities in the study area should be organised. This can reduce the constraints attached to land accessibility among migrants. Furthermore, Government, through the effort of rural planners at local level, can be saddled with the responsibility of identifying and making land available and accessible by clarifying and formalizing land use and land tenure arrangements for migrants in rural border settlements. This will reduce the burden attached to land accessibility (i.e. cost of renting and purchasing, ease of transfer and transaction amongst others) in the study area.

\section{References}

Afolayan A.A. 2010. Trans-Border Movement and Trading: A case study of a borderline in the Southwestern Nigeria. IFRA Trans-Border Studied, Occasional Publication, No 13, African Book Builders Ltd, Ibadan, Nigeria.

Agwu K., Amasiatu O.G., Onuoha O.U. 2010. Land Rights Characteristics and Access to land: Implications on Food 
Security in Nigeria. Journal of Environmental Issues and Agriculture in Developing Countries, 2, 2-3: 146-156.

Amselle J.-L. 1985. Ethnies et espaces: pour une anthropologie topologique. [in:] Au coeur de l'ethnie: ethnies, tribalisme et état en Afrique. La Découverte, Paris: 11-48.

Badu E., Owusu-Manu D., Edwards J.D., Adesi M., Lichtenstein S. 2013. Rural Infrastructure Development in the Volta Region of Ghana: Barriers and Interventions. Journal of Financial Management of Property and Construction, 18: 142-159.

Bello M.0. 2009. Squatter Settlement, Accessibility of Land and the Urban Poor. FIG Working Week, Eilat, Israel.

Bennett D.A. 2009. Project Genesis: Community Assessment of a Rural Southeastern Arizona Border Community. A Project requirement for the Degree of Doctor of Nursing Practice, submitted to the Faculty of College of Nursing, The University of Arizona.

Blum C.L. 1998. Land Tenure and Administration in Africa: Land Tenure and resource Access in Africa. IIED/FAO, London.

Boonyabancha S. 2009. Land for Housing the Poor - By the Poor: Experiences from the Baan Mankong Nationwide slum Upgrading Programme in Thailand. Environment \& Urbanization, 21(2): 309-329.

Chup C.D. 2004. Analysis of agroforestry practices in the guinea savannah ecological zone: A case study of the Federal Capital Territory of Nigeria. University of Jos, Nigeria.

Cotula L., Toulmin C. and Quan J. 2006. Better Land Access for the Rural Poor. Lessons from Experience and Challenges Ahead. IIED FAO. ISBN: 1-84369-632-0.

Department for International Development (DFID) 2007. Moving out of poverty - making migration work better for poor people.

Drechsel P., Dongus S. 2009. Dynamics and sustainability of urban agriculture: examples from sub-Saharan Africa. Integrated research System for Sustainability Science, 5: 69-78. DOI: 10.1007/s11625-009-0097-x.

ECOWAS -SWAC (Economic Community of West African States-Sahel and West Africa Club) 2006. Migration. Atlas on Regional Integration in West Africa.

Fadayomi T.0. 1998. Rural Development and Migration in Nigeria: Impact of the Eastern Zone of Bauchi State Agricultural Development Project. Nigeria Institute of Social and Economic Research, Ibadan, Nigeria.

Gbadegesin J.T., Heijden H., Boelhouwer P. 2016. Land Accessibility Factors in Urban Housing Provision in Nigeria Cities: Case of Lagos. Land Market and Housing Policy, 1.11. Paper No 9.

Ghebru H., Edey H., Ali D., Deininger K., Okumo A., Woldeyohannes S. 2014. Tenure security and demand for land tenure regularization in Nigeria: Empirical evidence from Ondo and Kano State. International Food Policy Research Institute, Working Paper, 25.

Harvey B. 2008. Audit of Community Development in the cross-border region. Cross Border Centre for Community Development, Institute of Technology, Dundalk, Co Louth.

International Fund for Agricultural Development (IFAD) 2001. The Rural Poverty Report (2001): Internal fund for Agricultural Development. Rome, Italy. http://www.ifad.org/ poverty/index.htm.

International Fund for Agricultural Development (IFAD) 2006. Housing and Urban Development, Government of Uganda Kampala.

International Fund for Agricultural Development (IFAD) 2015. Land Tenure Security and Poverty Reduction. IFAD: Investing in rural people. Paolo di Dono, 44-00142 Rome, Italy. www.ruralpovertyportal.org.
Johnson J.W., LeBreton J.M. 2004. History and Use of Relative Importance Indices in Organizational Research. Organizational Research Methods, 7, 238-257. DOI: $10.1177 / 1094428104266510$.

Lasterria-Cornhiel S., Garcia F. 2009. Gender and land rights: Findings and lessons from country studies. FAO Corporate Document Repository. Retrieved from www.fao.com

Mubvami T., Mushamba S., Veenhuizen R. (eds) 2003. Availability, access and usability of land for urban agriculture. Urban Agriculture Magazine, 11. RUAF, Leusden.

National Housing Policy. 1991. Federal Republic of Nigeria (FRN). Federal Government Press, Lagos.

Odudu C.O. 2015. Land accessibility among urban crop farmers in the informal sector, Lagos, Nigeria. Ethiopian Journal of Environmental Studies and Management, 8(2): 182-195.

Odudu O.C., Omirin M.M. 2012. Evaluating the constraints affecting land access among urban crop farmers in metropolitan Lagos. Journal of Agribusiness in Developing and Emerging Economics, 2(2): 130-146.

Odum C.O., Ibem E.0. 2011. Securing urban land for housing among low-income earners in sub-Sahara Africa: Case study of workers' cooperative society, Enugu, Nigeria. Human Geographies. Journal of Studies \& Research in Human Geography, 5.1, 61-75.

Ogun State, Central Department of Statistics, 2008.

Ogun State, Ministry of Land and Housing, 2017.

Ojiako A., Idowu O., Ogbukwa C. 2014. Determinant of loan repayment behaviour of smallholder cooperative farmers in Yewa North Local Government area of Ogun State, Nigeria. Journal of Economic and Sustainable Development, 5, 16: 144-153.

Oladehinde G.J. 2016. Migrants accessibility to land in rural border settlements of Ogun State Nigeria. Unpublished MSc Dissertation of the Department of Urban and Regional Planning, Obafemi Awolowo University, Ile-Ife, Nigeria.

Oladehinde G.J., Popoola K., Fatusin A., Adeyeni G. 2017. Land accessibility characteristics among migrants in Yewa North Local Government area of Ogun State, Nigeria. Asian Research Journal of Arts \& Social Sciences, 2(1): 1-12. ARJASS.30086.

Omirin M.M. 2002. Issues on land accessibility in Nigeria. Proceedings of the National Conference on Land Management and Taxation, University of Lagos, Lagos: 18-27.

Popoola K.O. 2016. Cross-Border Migrants' Integration in Rural Border Communities of South-West Nigeria. Journal of Sustainable Development Studies, 9(2): 138-152.

Udechukwu C. 2008. Obstacle to Individual Homeownership in Nigeria. International Journal of Housing Markets and Analysis, 1, 2: 182-194.

UN-Habitat. 1996. The Habitat agenda. www.unchs.org.

UN-Habitat. 2008. Secure Land Rights for All. GLTN contributes to the implementation of pro poor land policies to achieve secure land rights for all. www.gltn.net.

United Nations (UN) 1994. Strategies to Implement Human Settlement Policies on use change in Mashonal and provinces. Nordiska Afrika Institute, Uppsala.

Vélez-Guerra A. 2004. Multiple means of access to land for urban agriculture: A case study of farmers' groups in Bamako, Mali. International Development Research Centre.

Weber A. 2012. Boundaries with issues: Soft Border Management as a Solution? Perspective. Fes Eastern Africa, FriedrichEbert-Stiftung, Africa Department, Berlin, Germany.

Wills N. 2010. School-based professional support. Border Community Development Agency. Retrieved from: www.voiceofnigeria.org/Bordersecub.htm. 